\title{
Akermanite in the Cascade Slide Xenolith and Its Significance for Regional Metamorphism in the Adirondacks*
}

\author{
J.W. Valley ${ }^{1}$ and E.J. Essene \\ The University of Michigan, Department of Geological Sciences, Ann Arbor, Michigan 48109, USA
}

\begin{abstract}
Akermanite $\left(\mathrm{Ak}_{90}\right)$ coexists with monticellite $\left(\mathrm{Mo}_{92}\right)$ and wollastonite $\left(\mathrm{Wo}_{99}\right)$ in an unusual calc-silicate xenolith in anorthosite at Cascade Slide in the Adirondack Mountains, New York. Experimental results bearing on the stability of akermanite have been evaluated through calculations based on thermochemical data and by chemical analysis of experimental products (Yoder 1975). A temperature of $750^{\circ} \pm 30^{\circ} \mathrm{C}$ and a pressure less than $7 \mathrm{~kb}$ are inferred. These estimates are in agreement with the conditions of regional metamorphism previously inferred from other nearby rock types. When errors are considered, all existing data show that the Cascade Slide mineral assemblages last equilibrated at a slightly higher pressure of $7.4 \pm 1 \mathrm{~kb}$ and at a temperature of $750^{\circ} \pm 30^{\circ} \mathrm{C}$ during regional granulite facies metamorphism. The exotic mineralogy at Cascade Slide (akermanite, monticellite, cuspidine and wilkeite) was stabilized by low carbon dioxide fugacity. Posttectonic anorthosite intrusion is ruled out by the absence of a preserved contact aureole.
\end{abstract}

\section{Introduction}

An unusual occurrence of akermanite coexisting with monticellite and wollastonite has been found in a zoned xenolith of marble and calc-silicate at Cascade Slide within the anorthosite massif of the Adirondack Highlands. Although this xenolith contains a diverse suite of minerals that are typical of the sanidinite facies, previous estimates of metamorphic grade in all other rocks of the Adirondack Highlands show equilibration in the granulite facies. We have exam-

\footnotetext{
* Contribution No. 358 from the Mineralogical Laboratory, The University of Michigan, Ann Arbor, MI 48109, USA

1 Present address: Rice University, Department of Geology, Houston TX 77001, USA
}

ined the stability of akermanite-bearing assemblages in order to determine whether the xenolith last equilibrated in a post-tectonic aureole, during syntectonic regional metamorphism, or during pre-tectonic contact metamorphism. This question is critical to resolving the many conflicting theories of anorthosite genesis (de Waard 1969a) and the possibility of polymetamorphism in the Adirondacks.

Cascade Slide is located on the north side of Cascade Mountain above the outlet of Upper Cascade Lake in North Central Mt. Marcy Quadrangle, New York. Several blocks of metasediment are found as inclusions in anorthosite on Cascade Mountain. The largest is exposed in Cascade Slide with outcrop measuring about $30 \times 200 \mathrm{~m}$. This body has been previously investigated because of its unusual mineralogy (Emmons 1842; Kemp 1920; Baillieul 1976; Valley and Essene 1977, 1979; Tracy et al. 1978), but its metamorphic significance has not been completely understood. The writers have located two smaller marble xenoliths nearby, but neither contains comparable mineralogies.

Widespread evidence of assimilated metasediment can often be found on mountain tops in the vicinity of Cascade Mountain (Kemp 1920; Isachsen and Fisher 1970). This relationship suggests that this area was near the top of the anorthosite intrusion that engulfed xenoliths and roof pendants of orginally overlying rock units. At contacts there is always a silicated zone that may be as thin as $15 \mathrm{~cm}$ or as thick as $6 \mathrm{~m}$ separating the anorthosite from marble. One or more concentric zones are observed, with varying assemblages of: grossular-andradite, wollastonite, calcite, clinopyroxene, quartz or magnetite. It is likely that many of the compositional zones found at Cascade Slide, including the akermanite unit, represent varying degrees of metasomatic interaction between marble and anorthosite. However, the contact relationships are partially obscured by cover and it 
is also possible that the body is a synform as proposed by Baillieul (1976) based on detailed mapping. Some compositional banding in the calc-silicates could represent original sedimentary layers.

The granulite facies metamorphism of the Adirondack Highlands has been extensively studied (Buddington 1939; de Waard 1969b; Valley and Bohlen 1979). The overprint of this 1 b.y. Grenville event is so strong that sediments have completely recrystallized. Even dry, refractory igneous rocks have largely recrystallized and now contain garnets and/or pyroxenes of metamorphic composition (Bohlen and Essene 1978). Recent results (Bohlen et al. 1980 b; Valley and Essene 1980) indicate a gradual increase in metamorphic grade across the Adirondacks from $6 \pm 1 \mathrm{~kb}$, $650^{\circ} \pm 30^{\circ} \mathrm{C}$ at the amphibolite-granulite facies boundary in the northwest to $8 \pm 1 \mathrm{~kb}, 750^{\circ} \pm 30^{\circ} \mathrm{C}$ in the Central Adirondack Highlands. Temperatures of regional metamorphism have been contoured across the Adirondacks from K-feldspar-plagioclase and magnetite-ilmenite thermometry (Bohlen and Essene 1977; Bohlen et al. 1980 b). The $700^{\circ}$ and $750^{\circ} \mathrm{C}$ isotherms form roughly concentric curves around the anorthosite massif with higher temperatures toward the center. If the minerals at Cascade Slide equilibrated during regional metamorphism then these isotherms would lead one to predict a temperature slightly in excess of $750^{\circ} \mathrm{C}$.

Metamorphic pressure in the Adirondack Highlands is restricted by widespread occurrences of sillimanite that require pressures less than $9 \mathrm{~kb}$ at $700^{\circ}-$ $750^{\circ} \mathrm{C}$ (Newton 1966a; Richardson et al. 1968; Holdaway 1971). Such pressures are consistent with the assemblage fayalite + quartz in the Au Sable Quadrangle (20 km NNE of Cascade Slide), which yields a pressure less than $9.5 \pm 1 \mathrm{~kb}$ (Bohlen et al. 1980a) when the effects of impurities in the olivine are considered. In addition, scattered occurrences of iron-rich orthopyroxene restrict minimum pressures. Jaffe et al. (1978) report $F_{S_{95}}$ in charnockites $8 \mathrm{~km}$ to the west of Cascade Slide that restricts pressures to more than $7.8 \pm 1 \mathrm{~kb}$ when the effects of impurities are properly modeled (Bohlen et al. 1980a). Unfortunately neither sillimanite nor olivine + quartz has been found within the anorthosite massif. Thus, there is a possibility that pressures might be somewhat higher in Mt. Marcy Quadrangle. Jaffe et al. (1978) estimate pressures to be 8.5 to $11.5 \mathrm{~kb}$ at $750^{\circ} \mathrm{C}$ based on their interpretation of ferrosilite and fayalite + quartz assemblages, significantly overlapping the stability of kyanite. It will be shown, however, that if akermanite equilibrated during regional metamorphism, then its presence at Cascade Slide can be used to restrict these higher pressures, requiring metamorphism within the sillimanite field.
Melilite group minerals can form at high temperatures and low pressures by the contact metamorphism of impure limestone (Tilley 1929; Burnham 1959; Joesten 1974). At Scawt Hill in Ireland, melilite, larnite, merwinite and spurrite are developed at the contact of dolerite and chalk (Tilley 1929). At Crestmore, California, melilite is associated with many minerals that are also found at Cascade Slide, including grossular, diopside, wollastonite, vesuvianite, monticellite, cuspidine, forsterite, perovskite and spinel at the contact of limestone and quartz monzonite porphyry (Burnham 1959). Relatively pure akermanite is reported by Schaller (1916) at Mt. Vesuvius, where it occurs in metamorphosed blocks of impure limestone. In this study we report the first occurrence of akermanite in a high-grade regionally metamorphosed terrane and discuss its stability.

Akermanite, monticellite and sometimes wollastonite are generally considered to be index minerals of the sanidinite facies (Bowen 1940; Turner 1967). They are so characteristic that Winkler (1976) has proposed the terms monticellite-melilite zone and tilleyite-spurrite zone for low and high temperature subdivisions of the sanidinite facies. However, many studies have shown the importance of mixed volatiles in metamorphism (Greenwood 1967; Kerrick 1974) and because these minerals may form through volatilization reactions their stability cannot be considered in terms of pressure and temperature alone. Important reactions limiting their stability are:

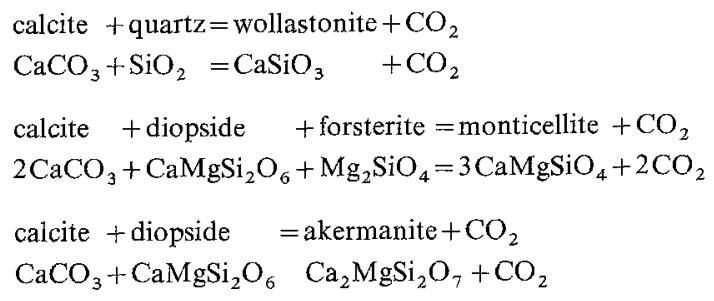

In each reaction higher $\mathrm{CO}_{2}$ pressure tends to stabilize the reactants while a decrease in $\mathrm{CO}_{2}$ pressure stabilizes the products, wollastonite, monticellite, or akermanite. At $8 \mathrm{~kb}$, the lithostatic pressure inferred for regional metamorphism of the Adirondack Highlands, these reactions require temperatures of $1,010^{\circ}$, $1,150^{\circ}$, and $1,150^{\circ} \mathrm{C}$ respectively if lithostatic pressure is equal to $\mathrm{CO}_{2}$ pressure (calculations based on experiments by Walter 1963; Greenwood 1967; Yoder 1975). Because these temperatures are $200^{\circ}$ to $400^{\circ} \mathrm{C}$ higher than other estimates for the Adirondacks and would cause massive in situ melting in adjacent feldspathic rocks for which there is no evidence, it has been suggested that lower values of $\mathrm{CO}_{2}$ pressure are likely (Valley and Essene 1977; Tracy et al. 1978). This could have resulted from dilution by other fluids, 
such as $\mathrm{H}_{2} \mathrm{O}$ or $\mathrm{CH}_{4}$, or from the absence of a free metamorphic fluid such that $\mathrm{CO}_{2}$ activities were buffered by solid phases only (Valley and Essene 1977, 1979). These two possibilities should always be considered when working with volatilization reactions, especially in the granulite facies, and will be the subject of a second paper by the authors on Cascade Slide. A third possibility, that these minerals were stabilized during pre- or post-tectonic contact metamorphism, at much lower lithostatic pressure, is inconsistent with other solid-solid equilibria at Cascade Slide, as will be shown in this paper. Thus Bowen's (1940) index minerals for marbles are of little use in determining either metamorphic temperature or facies unless the fugacity of $\mathrm{CO}_{2}$ can be defined.

\section{Mineralogy and Texture}

Mineral assemblages from the calc-silicate bodies on Cascade Mountain are listed in Table 1. Only those minerals are listed that are inferred to be in chemical equilibrium from the criteria described below. Common minerals include calcite (often sky-blue in hand specimen), pyroxene $\left(\mathrm{Di}_{97-50}\right)$, garnet $\left(\mathrm{Gr}_{80-40}\right)$, wollastonite, monticellite, scapolite $\left(\mathrm{Me}_{40-80}\right)$, magnetite, $\mathrm{K}$-feldspar and plagioclase. Less commonly, assemblages may contain forsterite, akermanite, spinel, tremolite, quartz, sphene, tourmaline, apatite, sphalerite, pyrite, pyrrhotite, galena, perovskite, harkerite, cuspidine, wilkeite and vesuvianite. Phlogopite and graphite have been reported in float at Cascade Slide (Baillieul 1976) but have not yet been found in place. This paper is the first report of akermanite, cuspidine and wilkeite in the Adirondacks and, to the writers' knowledge, in any granulite facies terrane.

Mineral textures in Adirondack marbies and calc-silicates typically indicate metamorphic annealing, often with $120^{\circ}$ grain boundary angles. The domain of a thin section is assumed to represent equilibrium except in banded rocks or where minerals are zoned. Equilibrium assemblages have not been inferred across bands of different mineralogy because of the possibility that gradients in chemical potentials exist. Equilibrium has been assumed within individual bands that are likely to represent domains of constant chemical potential in the absence of mineral zoning. Retrograde textures such as rimming or exsolution that are easily recognized elsewhere in Adirondack marbles (Valley and Essene 1980) have been avoided. Many cuspidine-bearing samples, including LP 77$210-10$, contain $30 \%$ alteration that is fine grained and chemically heterogeneous at the scale of microprobe analysis. This alteration does not appear to have formed at the expense of any of the minerals that were analyzed, except sometimes wollastonite (Fig. 1 b), and probably indicates the former presence of additional minerals that may have been stable at the peak of metamorphism. Powder X-ray diffraction and qualitative electron microprobe anal$y$ sis of a few areas of alteration have failed to reveal the identify of such former minerals.

Two generations of wollastonite and monticellite occur with occasional crystals of akermanite. Coarse, discrete grains of each mineral (Fig. 1a, b) are found in thin section along with a finegrained, graphic intergrowth. The intergrowths consist of wollastonite and monticellite in a symplectic texture (Fig. 1 c). It is assumed that the coarse grains of wollastonite and monticellite were in equilibrium with akermanite at the peak of metamorphism, but the intergrowths may represent back-reaction of akermanite. Similar intergrowths from carbonate xenoliths in gabbro of the Bushveld Complex are reported by Willemse and Bensch (1964) and interpreted to represent retrograde reaction of akermanitic melilite. The same conclusion was made by Harker and Tuttle (1956) for intergrowths at Crestmore, although Burnham (1959) interprets them as a metasomatic replacement of preexisting intergrowths of monticellite with spurrite, merwinite or cuspidine.

\section{Akermanite Stability in the System $\mathrm{CaO}-\mathrm{MgO}-$ $\mathrm{SiO}_{2}$}

An estimate of pressure and temperature at Cascade Slide may be obtained from solid-solid reactions involving akermanite. Five applicable reactions have

Table 1. Mineral assemblages identified in thin section from Cascade Mt. The * indicates minerals that have been quantitatively analyzed. Approximate compositions when given were determined by energy dispersive analysis. LP samples are from this study; CL is from Tracy et al. (1978) and $\mathrm{Cl}$ is from Baillieul (1976). Mineral abbreviations are : $\mathrm{Cc}=$ calcite; $\mathrm{Cpx}=$ clinopyroxene; Fo =forsterite; Gn=garnet; $\mathrm{Mo}=$ monticellite; $\mathrm{Wo}_{\mathrm{O}}=$ wollastonite

\begin{tabular}{|c|c|c|c|c|c|c|c|}
\hline & $\mathrm{Cc}$ & $\mathrm{Cpx}$ & Mo & Fo & Wo & Gn & \\
\hline LP $77-201$ & $\mathrm{x}$ & $\mathrm{x}^{*}$ & $x^{*}$ & $x^{*}$ & & & spinel*, wilkeite, sphalerite \\
\hline LP 77-201-1 & $\mathrm{x}$ & & & & & & tremolite $*$, tourmaline \\
\hline LP 77-201-2 & $\mathrm{x}$ & $\mathrm{x}$ & & & $\mathrm{x}$ & $\mathrm{x}$ & \\
\hline LP 77-201-5 & $\mathrm{x}$ & $\mathrm{x}$ & $\mathrm{x}$ & & & & spinel, apatite, vesuvianite \\
\hline LP 77-210-1 & & $\mathrm{x}$ & & & & & magnetite \\
\hline LP $77-210-5$ & $\mathrm{x}$ & $\mathrm{x}$ & & & & $\mathrm{x}$ & pyrrhotite \\
\hline LP $77-210-10$ & & $\mathrm{x}^{*}$ & $x^{*}$ & & $x^{*}$ & $x^{*}$ & akermanite ${ }^{*}$, cuspidine ${ }^{*}$ \\
\hline LP $78-210-6$ & $\mathrm{x}$ & $\mathrm{x}$ & & & & $\mathrm{x}$ & garnet-clinopyroxene, symplectite \\
\hline LP 201-3 & $x$ & $\mathrm{x}$ & & & & $\mathrm{x}$ & quartz, sphene \\
\hline LP 201-3a & & $\mathrm{x}$ & & & & $x^{*}$ & quartz, sphene, plagioclase, K-feldspar, apatite \\
\hline LP 201-3b & $\mathrm{x}$ & $\mathrm{x}$ & & & & & sphalerite, pyrite \\
\hline LP $201-3 c$ & $x$ & $\mathrm{x}$ & & & & & sphalerite, pyrite, pyrrhotite \\
\hline LP $201-34$ & & $\mathrm{x}$ & & & & $x^{*}$ & quartz, K-feldspar, plagioclase, sphene, apatite \\
\hline LP 201-4 & $\mathrm{x}$ & $\mathrm{x}$ & $\mathrm{x}$ & & & $\mathrm{x}$ & spinel \\
\hline $\mathrm{Cl}-1 \mathrm{~h}$ & & & & & & & harkerite, perovskite \\
\hline CL-3a & $\mathrm{x}$ & $\mathrm{x}$ & $x^{*}$ & $x^{*}$ & & & spinel $^{*}$, vesuvianite* \\
\hline
\end{tabular}



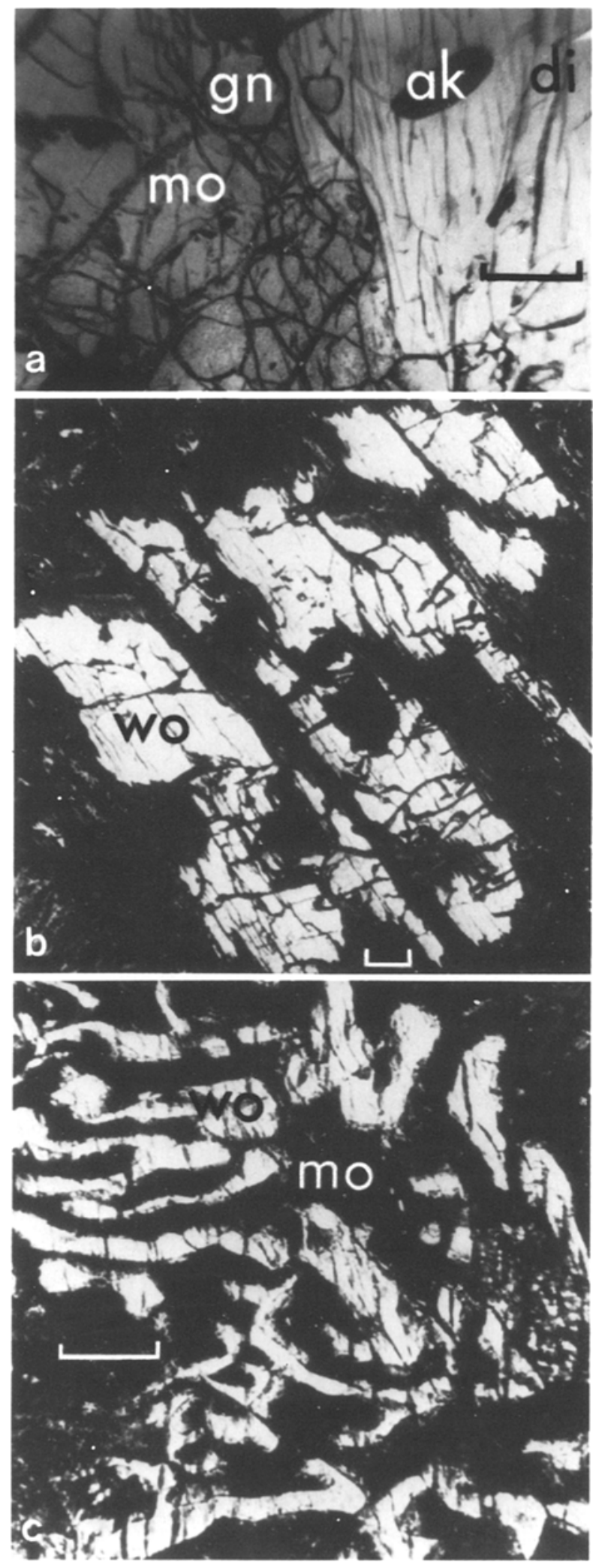

Fig. 1. a Photomicrograph of LP 77-210-10 showing coexisting akermanite, monticellite, diopside and garnet. Scale bar is $1,000 \mu \mathrm{m}$. Elsewhere in this thin section are cuspidine and wollastonite. Analyses of these minerals are in Table $4 . \mathbf{b}$ and $\mathbf{c}$ Photomicrographs of LP 78-210-10-2. This sample was collected within one meter of LP 77-210-10 from the same rock unit and is mineralogically similar although the wollastonite-monticellite intergrowths are better developed. Figure $1 \mathrm{~b}$ shows primary, coarse, optically continuous wollastonite that is broken with fine-grained, heterogeneous alteration along fractures. Scale bar is $200 \mu \mathrm{m}$. Figure $1 \mathrm{c}$ shows a fine-grained intergrowth of optically continuous monticellite and wollastonite. Scale bar is $100 \mu \mathrm{m}$. Note the $5 x$ magnification over Fig. $1 \mathrm{~b}$ 
been experimentally calibrated in the system $\mathrm{CaO}-$ $\mathrm{MgO}-\mathrm{SiO}_{2}$ :

$$
\begin{aligned}
& \text { akermanite }=\text { wollastonite }+ \text { monticellite } \\
& \mathrm{Ca}_{2} \mathrm{MgSi}_{2} \mathrm{O}_{7}=\mathrm{CaSiO}_{3}+\mathrm{CaMgSiO}_{4} \\
& \text { akermanite }=\text { diopside }+ \text { merwinite } \\
& 2 \mathrm{Ca}_{2} \mathrm{MgSi}_{2} \mathrm{O}_{7}=\mathrm{CaMgSi}_{2} \mathrm{O}_{6}+\mathrm{Ca}_{3} \mathrm{MgSi}_{2} \mathrm{O}_{8} \\
& \text { monticellite + diopside =akermanite + forsterite } \\
& 3 \mathrm{CaMgSiO}_{4}+\mathrm{CaMgSi}_{2} \mathrm{O}_{6}=2 \mathrm{Ca}_{2} \mathrm{MgSi}_{2} \mathrm{O}_{7}+\mathrm{Mg}_{2} \mathrm{SiO}_{4} \\
& \text { monticellite }=\text { merwinite } \quad+\text { forsterite } \\
& 3 \mathrm{CaMgSiO}_{4}=\mathrm{Ca}_{3} \mathrm{MgSi}_{2} \mathrm{O}_{8}+\mathrm{Mg}_{2} \mathrm{SiO}_{4} \\
& \text { wollastonite }+ \text { monticellite }=\text { diopside }+ \text { merwinite } \\
& 2 \mathrm{CaSiO}_{3}+2 \mathrm{CaMgSiO}_{4}=\mathrm{CaMgSi}_{2} \mathrm{O}_{6}+\mathrm{Ca}_{3} \mathrm{MgSi}_{2} \mathrm{O}_{8}
\end{aligned}
$$

These reactions are plotted in Fig. 2 along with the reversals of Harker and Tuttle (1956) and Yoder (1975) for reaction (4), Kushiro and Yoder (1964) and Yoder (1975) for reaction (5), Walter (1963) and Yoder (1968) for reaction (6), Yoder (1968) for reaction (7), and Yoder (1975) for reaction (8). Because coexisting akermanite + wollastonite + monticellite are found at Cascade Slide, the $P-T$ conditions must lie along reaction (4) but at lower pressure than the invariant point $[\mathrm{Fo}]$.

The $P-T$ location of all reactions in Fig. 2 have been calculated by the computer program EQUILI (Wall and Essene 1972) from the relation:

$\Delta G_{\mathrm{r}}\left(P_{2} T_{2}\right)-\Delta G_{\mathrm{r}}\left(P_{1} T_{1}\right)=-\int_{T_{1}}^{T_{2}} \Delta S_{\mathrm{r}} d T+\int_{P_{2}}^{P_{2}} \Delta V_{\mathrm{r}} d P$

Details of this program are described elsewhere (Valley and Essene 1980). Necessary entropy data are given in Table 2. Values of $V_{298}$ are taken when available from Robie et al. (1978) except for merwinite which is from Moore and Araki (1972). Thermal expansion is calculated from data in Skinner (1966) and compressibility from Birch (1966). When not available these values are estimated from data on structurally and chemically related minerals.

The experimentally determined reaction slopes in Fig. 2 are generally consistent with calculated slopes except for reactions (5) and (6). For reaction (5) the calculated slope is $+131^{\circ} / \mathrm{kb}$ whereas the experimental reversals require a slope of $+85^{\circ} / \mathrm{kb}$. A possible explanation of this discrepancy is that solid solution at high temperatures has shifted the experimental reaction relative to end-member minerals. This explanation has also been proposed by Helgeson et al. (1978) to explain inconsistencies between their thermodynamic data and Yoder's (1968) experiments for reaction (6). For example, if the diopside and merwinite grown in the experiments of Yoder (1975) were mutu-

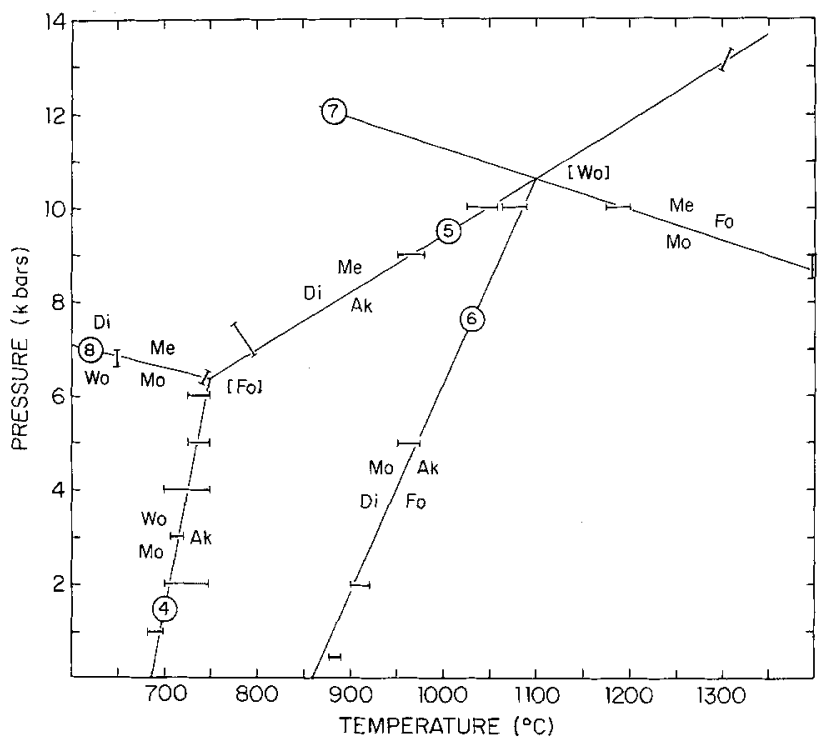

Fig. 2. Pressure-temperature diagram of reactions (4) through (8) for end-member compositions in the ideal system $\mathrm{CaO}-\mathrm{MgO}-$ $\mathrm{SiO}_{2}$

ally soluble then the experimentally determined equilibrium for reaction (5) will be shifted to lower pressures. If the experimentally grown akermanite is a solid solution (within the system $\mathrm{CaO}-\mathrm{MgO}-\mathrm{SiO}_{2}$ ), the reaction will be shifted to higher pressures. Thus significant solid solution could explain the difference between the calculated and experimental slope. An alternative explanation for this discrepancy is that errors in entropy and/or volume result in an error in the calculated slope. Increase of calculated $\Delta V_{\mathrm{r}}$ by $0.75 \mathrm{~J} /$ bars (from -2.11 to -1.36 ) or decrease in $\Delta S_{\mathrm{r}}$ by $8.8 \mathrm{~J} / \mathrm{mol}^{\circ} \mathrm{K}$ (from -16.0 to -24.8 ) would be required to account for the disagreement. Such a change in $\Delta S_{\mathrm{r}}$ would correspond to a $1-3 \%$ change in $S_{T}$ for either merwinite or akermanite. Such an error is not unlikely as the heat capacities of merwinite and akermanite have only been measured above $50^{\circ} \mathrm{K}$. If the volume of merwinite given by Robie et al. (1978) $(10.44 \mathrm{~J} /$ bar $)$ is used rather than that of Moore and Araki (1972) (9.848 J/bar), then much of the discrepancy is removed. Moore and Araki summarize five other studies consistent with their own careful measurements, whereas Robie et al. estimated volume from density data and Robie now accepts the Moore and Araki value (Robie, personal communication, 1979). Thus, the volume data of Moore and Araki are to be preferred and assignment of the slope discrepancy to errors in the volume of merwinite alone cannot be justified. The calculated slope for reaction (5) will be more accurately estimated when the heat capacities of merwinite and akermanite have been measured to low temperatures, thereby decreasing uncertainties in the entropy data base. 
Table 2. Volume and entropy of minerals used in EQUILI: $V_{298}^{\circ}$ in $\mathrm{cm}^{3} / \mathrm{mol} ; S_{\mathrm{T}}^{\circ} S_{298}^{\circ}=A \cdot \ln T+B \cdot 10^{-3} \cdot T+C \cdot 10^{5} T^{-2}+D(T$ in ${ }^{\circ} \mathrm{K}, S$ in cal $/ \mathrm{mol}^{\circ}{ }^{\circ}$. Note: to convert to S.I. units as is done in the text, divide $V$ by 10 and multiply $S$ by 4.1840

\begin{tabular}{|c|c|c|c|c|c|c|c|c|c|}
\hline & $V_{298}^{\circ}$ & Source & $S_{298}^{\circ}$ & Source & $A$ & $B$ & $C$ & $D$ & Source \\
\hline Akermanite & 92.81 & (1) & 50.031 & (1) & 60.972092 & 10.781864 & 6.3927813 & -357.76 & (1) \\
\hline Anorthite & 100.79 & (1) & 47.63 & (1) & 36.177765 & 40.583145 & -9.3403101 & -210.03 & (1) \\
\hline Calcite & 36.934 & (1) & 21.92 & (1) & 24.597229 & 5.6011763 & 2.918417 & -145.09 & (1) \\
\hline Diopside & 66.09 & (1) & 34.106 & (2) & 56.563293 & 5.5108109 & 12.942201 & -335.71 & (1) \\
\hline Forsterite & 43.79 & (1) & 22.49 & (2) & 35.966522 & 6.6885138 & 4.6139383 & -212.13 & (1) \\
\hline Grossular & 125.30 & (1) & 60.96 & (3) & 107.96191 & 13.708772 & 16.051285 & -637.33 & (3) \\
\hline Merwinite & 98.48 & (6) & 60.499 & (1) & 73.798569 & 11.307795 & 7.7449579 & -432.57 & (1) \\
\hline Monticellite & 51.36 & (1) & 25.64 & (4) & 34.322296 & 9.1385698 & 3.7102203 & -202.46 & (4) \\
\hline Quartz & 22.688 & (1) & 9.909 & (1) & 11.100000 & 8.3889999 & 1.3310003 & -67.24 & (1) \\
\hline Wollastonite & 39.93 & (1) & 19.37 & (5) & 26.386215 & 3.8636436 & 3.1771917 & -155.05 & (1) \\
\hline
\end{tabular}

Sources: (1) Robie et al. (1978); (2) Robie (pers. comm., 1979); (3) Westrum et al. (1979); (4) $\mathrm{S}_{\mathrm{Mo}}=1 / 2\left(S_{\mathrm{Forsterite}}+S_{\mathrm{Ca}-\mathrm{olivine}}\right) ;(5)$ Haas et al. (1979); (6) Moore and Araki (1972)

Because the location of reaction (5) is critical to restricting pressures at Cascade Slide, the possibility of solid solution in experimental run products was carefully investigated. The run products in experiments reported by Yoder (1975) were not analyzed by electron microprobe. Dr. Yoder was contacted concerning analysis of these run products and he has kindly provided the products of 33 capsules for reactions (4) and (5). Several of the run products were coarse enough to analyze and the results show that the products are stoichiometric within analytical errors (Table 3). The phases analyzed were crystalline diopside, akermanite and merwinite, from 5 to $50 \mu \mathrm{m}$ in diameter. The coarsest of these, merwinite, contained visible fluid inclusions. Slightly low analytical totals $(97.5-99.2 \%)$ are attributed to the small grain size and to these inclusions. Thus Yoder's (1975) experiments appear to be applicable to the endmember reaction (5) and will be used in this paper in preference to calculated curves.

The conclusion that akermanite + diopside + merwinite show no mutual solid solution at the relevant temperatures can be used to make a qualitative evaluation of the importance of solid-solution for reaction (6). Forsterite and monticellite show 3-4\% mutual solid solution across an approximately symmetric solvus at $10 \mathrm{~kb}, 1,100^{\circ} \mathrm{C}$ (Warner and Luth 1973). If diopside and akermanite solutions in forsterite and monticellite are assumed to be negligible then the shift of Yoder's (1968) experiments relative to the end-member reaction can be calculated. Because the stoichiometry of reaction (6) involves 3 moles of monticellite reacting to 1 mole of forsterite, the resulting equilibrium coefficient will be less than unity and the experimental curve will be at higher temperatures than the end-member reaction. This location of the end-member reaction (6) at lower temperatures than the experiments is the opposite of the conclusion of Helgeson (1978) that the end-member reaction is lo-
Table 3. Electron microprobe analyses of experimental run products from Yoder (1975). Abbreviations are: $\mathrm{Ak}=$ akermanite; $\mathrm{Di}=$ diopside; $\mathrm{Me}=$ merwinite. All runs were with excess $\mathrm{H}_{2} \mathrm{O}$. Experimental conditions were: run $83,880^{\circ} \mathrm{C}, 8.0 \mathrm{~kb}$; runs 28 and 29 , $750^{\circ} \mathrm{C}, 6.5 \mathrm{~kb}$

\begin{tabular}{lccccc}
\hline & Ak 83 & Me 28 & Di 28 & Me 29 & Di 29 \\
\hline $\mathrm{SiO}_{2}$ & 43.31 & 35.29 & 54.04 & 35.47 & 54.51 \\
$\mathrm{MgO}$ & 15.17 & 12.24 & 18.33 & 12.25 & 18.31 \\
$\mathrm{CaO}$ & 40.71 & 49.97 & 25.67 & 50.46 & 25.84 \\
\hline $\mathrm{SUM}$ & 99.19 & 97.50 & 98.04 & 98.19 & 98.66 \\
\hline $\mathrm{Si}$ & 1.992 & 1.978 & 1.985 & 1.974 & 1.994 \\
$\mathrm{Mg}$ & 1.024 & 1.022 & 1.004 & 1.017 & 0.994 \\
$\mathrm{Ca}$ & 1.986 & 3.000 & 1.011 & 3.009 & 1.010 \\
$\mathrm{O}$ & 6.994 & 7.978 & 5.985 & 7.974 & 5.992 \\
\hline
\end{tabular}

cated some $400^{\circ} \mathrm{C}$ above Yoder's reversals. Helgeson chose the value of $\Delta G_{\mathrm{f}}^{\circ}$ for monticellite that is reported in Robie et al. (1978). Valley and Essene (1979) have found that values of $\Delta G_{\mathrm{f}}^{\mathrm{o}}$ derived from Yoder's experiments on reaction (4) are more consistent with other monticellite experiments (Walter 1963). We propose that in many cases more accurate $\Delta G_{\mathrm{f}}^{\circ}$ (and hence $\left.\Delta H_{\mathrm{f}}^{\circ}\right)$ can be derived from carefully reversed solidsolid experiments where potential solid solutions have been evaluated. In the case of invariant points [Fo] and [Wo] in Fig. 1, this calculation of $\Delta G_{\mathrm{f}}^{\circ}$ requires knowledge of $\Delta G_{\mathrm{f}}^{\circ}$ for only two minerals to uniquely fix the value of $\Delta G_{f}^{\circ}$ for the remaining four phases.

\section{Effect of Solid Solution on Akermanite Equilibria}

The extent of solid solution in certain critical minerals was evaluated by wavelength-dispersive electron microprobe analysis (Table 4). Minerals are normalized around expected cations, assuming no vacancies, which permits estimation of $\mathrm{Fe}^{3+}$. The details of anal- 
Table 4. Electron microprobe analysis of minerals from Cascade Slide

\begin{tabular}{|c|c|c|c|c|c|c|c|c|c|c|c|c|}
\hline & 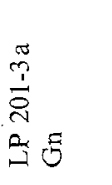 & 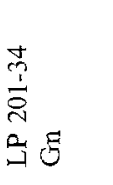 & 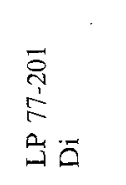 & 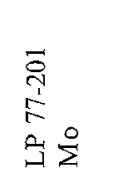 & 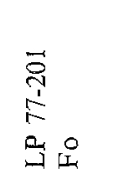 & 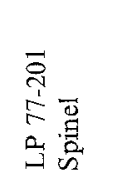 & 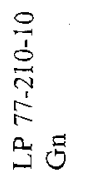 & 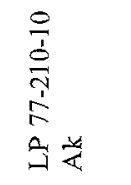 & 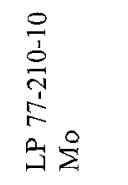 & 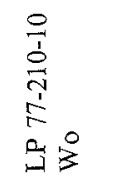 & 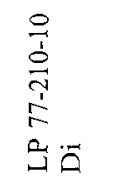 & 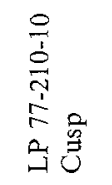 \\
\hline $\mathrm{SiO}_{2}$ & 38.85 & 38.96 & 50.63 & 37.13 & 41.30 & $\leqq 0.05$ & 37.18 & 44.07 & 38.40 & 51.81 & 55.06 & 32.77 \\
\hline $\mathrm{TiO}_{2}$ & 0.28 & 0.27 & 0.44 & $\leqq 0.05$ & 0.05 & $\leqq 0.05$ & 1.55 & 0.05 & 0.05 & $\leqq 0.05$ & 0.08 & 0.08 \\
\hline $\mathrm{AL}_{2} \mathrm{O}_{3}$ & 18.71 & 17.84 & 4.28 & $\leqq 0.05$ & $\leqq 0.05$ & 60.29 & 8.24 & 0.33 & 0.03 & $\leqq 0.05$ & 0.48 & $\leqq 0.05$ \\
\hline $\mathrm{Fe}_{2} \mathrm{O}_{3}{ }^{\mathrm{b}}$ & 4.55 & 6.38 & 0.00 & 0.00 & 0.00 & 7.45 & 17.80 & 0.00 & 0.00 & $\leqq 0.05$ & 0.89 & $\leqq 0.05$ \\
\hline $\mathrm{FeO}^{\mathrm{b}}$ & 2.54 & 2.05 & 1.86 & 3.99 & 3.37 & 2.05 & 0.00 & 0.47 & 3.92 & $\leqq 0.05$ & 0.00 & $\leqq 0.05$ \\
\hline $\mathrm{MnO}$ & 0.25 & 0.31 & $\leqq 0.05$ & 0.45 & 0.38 & 0.23 & 0.10 & 0.11 & 0.84 & $<0.05$ & $\leqq 0.05$ & $\leqq 0.05$ \\
\hline $\mathrm{MgO}$ & 0.22 & 0.18 & 16.53 & 23.61 & 54.68 & 18.85 & 0.68 & 12.87 & 22.16 & 0.07 & 17.98 & 0.08 \\
\hline $\mathrm{CaO}$ & 34.52 & 33.76 & 25.93 & 35.15 & 0.26 & $\leqq 0.05$ & 34.53 & 40.09 & 36.50 & 48.38 & 26.71 & 61.00 \\
\hline $\mathrm{Na}_{2} \mathrm{O}$ & - & - & - & - & - & - & $\leqq 0.05$ & $\leqq 0.05$ & $\leqq 0.05$ & $\leqq 0.05$ & $\leqq 0.05$ & $\leqq 0.05$ \\
\hline $\mathrm{ZnO}$ & - & - & $\leqq 0.05$ & 0.10 & 0.05 & 11.28 & 0.06 & 1.56 & 0.17 & 0.12 & 0.10 & 0.14 \\
\hline $\mathrm{Cl}$ & - & - & - & - & - & - & - & - & - & - & - & $\leqq 0.05$ \\
\hline$F$ & - & - & - & - & - & - & - & - & - & - & - & 10.06 \\
\hline $\mathrm{H}_{2} \mathrm{O}^{\mathrm{b}}$ & - & - & - & - & - & - & - & - & - & - & - & 0.15 \\
\hline $\mathrm{SUM}^{\mathrm{a}}$ & 99.94 & 99.75 & 99.67 & 100.43 & 100.09 & 100.15 & 100.14 & 99.52 & 102.07 & 100.39 & 101.30 & 100.10 \\
\hline $\mathrm{O}^{\mathrm{b}}$ & 12.000 & 12.000 & 5.943 & 3.977 & 3.982 & 4.002 & 12.007 & 7.045 & 4.006 & 3.000 & 5.992 & 7.041 \\
\hline $\mathrm{Si}$ & 2.982 & 3.013 & 1.841 & 0.978 & 0.981 & 0.001 & 2.986 & 2.034 & 1.004 & 0.999 & 1.969 & 1.988 \\
\hline Al & 0.018 & 0.000 & 0.159 & $\leqq 0.001$ & $\leqq 0.00 \mathrm{I}$ & 1.853 & 0.014 & 0.000 & 0.000 & $\leqq 0.001$ & 0.020 & $\leqq 0.003$ \\
\hline $\mathrm{Al}$ & 1.675 & 1.627 & 0.025 & 0.000 & 0.000 & - & 0.765 & 0.018 & 0.001 & 0.000 & 0.000 & 0.000 \\
\hline $\mathrm{Fe}^{3+b}$ & 0.307 & 0.321 & 0.000 & 0.000 & 0.000 & 0.147 & 1.077 & 0.000 & 0.000 & $\leqq 0.001$ & 0.024 & $\leqq 0.002$ \\
\hline $\mathrm{Fe}^{2+b}$ & 0.120 & 0.184 & 0.057 & 0.088 & 0.067 & 0.045 & 0.000 & 0.018 & 0.086 & $\leqq 0.001$ & 0.000 & $\leqq 0.002$ \\
\hline $\mathrm{Ti}$ & 0.018 & 0.015 & 0.011 & $\leqq 0.001$ & 0.001 & $\leqq 0.001$ & 0.094 & 0.002 & 0.001 & $\leqq 0.001$ & 0.002 & 0.003 \\
\hline $\mathrm{Mg}$ & 0.025 & 0.021 & 0.896 & 0.928 & 1.936 & 0.733 & 0.082 & 0.886 & 0.864 & 0.002 & 0.958 & 0.007 \\
\hline $\mathrm{Mn}$ & 0.016 & 0.020 & $\leqq 0.002$ & 0.010 & 0.008 & 0.005 & 0.006 & 0.004 & 0.019 & $\leqq 0.001$ & $\leqq 0.002$ & $\leqq 0.002$ \\
\hline $\mathrm{Zn}$ & - & - & $\leqq 0.002$ & 0.002 & 0.001 & 0.217 & 0.004 & 0.054 & 0.003 & 0.002 & 0.003 & 0.006 \\
\hline $\mathrm{Ca}$ & 2.839 & 2.797 & 1.010 & 0.993 & 0.006 & $\leqq 0.001$ & 2.971 & 1.984 & 1.023 & 0.998 & 1.023 & 3.986 \\
\hline $\mathrm{Na}$ & - & - & - & - & - & - & $\leqq 0.004$ & $\leqq 0.003$ & $\leqq 0.001$ & $\leqq 0.001$ & $\leqq 0.001$ & $\leqq 0.003$ \\
\hline $\mathrm{Cl}$ & - & - & - & - & - & - & - & - & - & - & - & $\leqq 0.002$ \\
\hline F & - & - & - & - & - & - & - & - & - & - & - & 1.940 \\
\hline \multirow[t]{2}{*}{$\mathrm{OH}^{\mathrm{b}}$} & - & - & - & - & - & - & - & - & - & - & - & 0.060 \\
\hline & $\begin{array}{l}\alpha_{\mathrm{Gr}} \\
=0.594\end{array}$ & $\begin{array}{l}\alpha_{\mathrm{Gr}} \\
=0.544\end{array}$ & $\begin{array}{l}\alpha_{D i} \\
=0.906\end{array}$ & $\begin{array}{l}\alpha_{M_{0}} \\
=0.921\end{array}$ & $\begin{array}{l}\alpha_{F_{0}} \\
=0.920\end{array}$ & $\begin{array}{l}\alpha_{\mathrm{Sp}} \\
=0.629\end{array}$ & & $\begin{array}{l}\alpha_{\text {Ak }} \\
=0.902\end{array}$ & $\begin{array}{l}\alpha_{M_{0}} \\
=0.887\end{array}$ & $\begin{array}{l}\alpha_{W_{0}} \\
=0.996\end{array}$ & \multicolumn{2}{|l|}{$\begin{array}{l}\alpha_{\mathrm{Di}} \\
=0.970\end{array}$} \\
\hline
\end{tabular}

Adjusted for $\mathrm{Fe}_{2} \mathrm{O}_{3}, \mathrm{~F}=\mathrm{O}$ and $\mathrm{H}_{2} \mathrm{O}$

b Calculated from normalized formula

ysis and normalization are discussed elsewhere (Valley and Essene 1980).

It is significant to note that in sample LP 77-210. 10 , which contains akermanite coexisting with five other minerals, all phases are near to end-member compositions except garnet. Thus, end-member reactions involving any of these phases will approximate their stability and only small corrections are necessary for solid solution. It will be shown below that such corrections can be modeled for nearly end-member phases, but that the lack of activity coefficient data could introduce large errors for phases that deviate greatly from end-member composition.

It is also significant that elements are highly fractionated among the minerals of LP 77-210-10. The ions $\mathrm{Fe}^{3+}, \mathrm{Ti}$, and $\mathrm{Al}$ are strongly concentrated in garnet, whereas akermanite concentrates $\mathrm{Zn}$ and monticellite concentrates $\mathrm{Mn}$ and $\mathrm{Fe}^{2+}$. Thus $\mathrm{Zn}$ stabilizes akermanite and shifts reaction (4) to significantly lower temperatures but $\mathrm{Mn}$ and $\mathrm{Fe}^{2+}$ have a somewhat compensatory effect. It becomes very important to consider all substitutions when minerals show such large fractionation of elements, particularly for solid-solid equilibria with small values of $\Delta V_{\mathrm{r}}$ and/or $\Delta S_{\mathrm{r}}$.

The change in pressure of a reaction due to substitutions can be calculated from the relation:

$-\triangle P \Delta V=R \cdot T \cdot \ln K$

where $K$ is the equilibrium constant. Because the nec- 


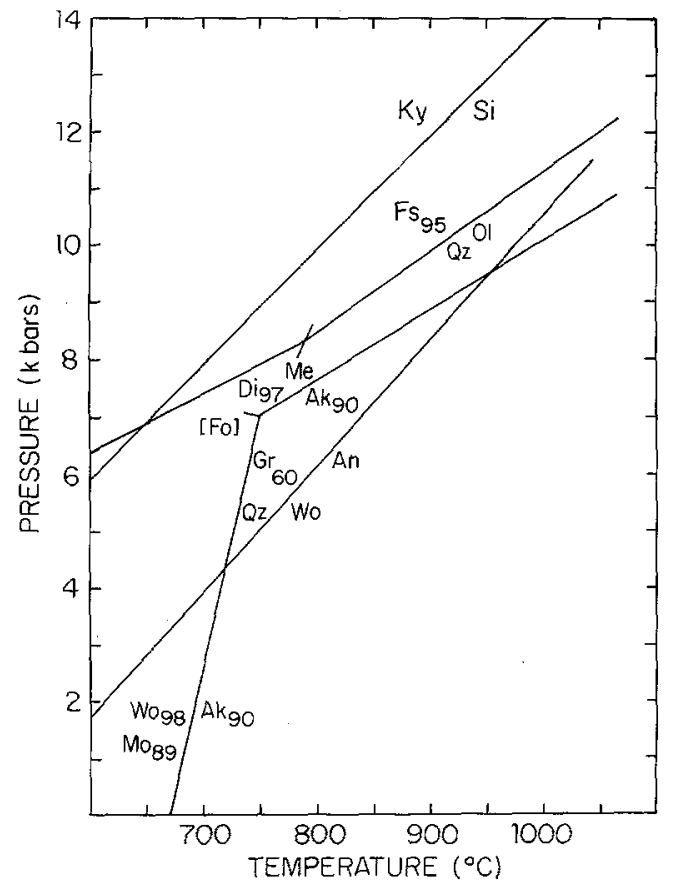

Fig. 3. Pressure-temperature diagram of reactions adjusted for mineral activities appropriate to this study: wollastonite $(0.98)+$ monticellite $(0.89)=$ akermanite $(0.90)$; akermanite $(0.90)=$ diopside $(0.97)+$ merwinite $;$ grossular $(0.60)+$ quartz $=$ wollastonite + anorthite; ferrosilite (mole fraction $=0.95)=$ olivine + quartz; kyanite $=$ sillimanite

essary activity vs. composition relations have not been experimentally measured, activities have been calculated using a modified version of the ideal ionic model (Kerrick and Darken 1975), considering independent substitutions on a site-by-site basis such that:

$$
\begin{aligned}
& \alpha_{\mathrm{AK}}=\alpha_{\mathrm{C}_{2} \mathrm{MGS}_{\mathrm{M}} \mathrm{S}_{2} \mathrm{O}_{7}}^{\text {melite }}=\left(X_{\mathrm{Ca}}\right)^{2}\left(X_{\mathrm{Mg}_{\mathrm{g}}}\right) \\
& \alpha_{\mathrm{Mo}}=\alpha_{\mathrm{CanMgSiO}}^{\text {monicellite }}=\left(X_{\mathrm{Ca}}\right)\left(X_{\mathrm{Mg}}\right) \\
& \alpha_{\mathrm{Mo}_{0}}=\alpha_{\mathrm{CASSO}_{3}}^{\text {wolliastonite }}=\left(X_{\mathrm{Ca}}\right) \\
& \alpha_{\mathrm{Di}}=\alpha_{\mathrm{CaMgSiO}}^{\text {clinoproxene }}=\left(X_{\mathrm{Ca}}\right)\left(X_{\mathrm{Mg}}\right) \\
& \alpha_{G_{r}}=\alpha_{\mathrm{C}_{3} \mathrm{~A}_{2} 2 \mathrm{i}_{3} \mathrm{O}_{12}}^{\mathrm{ganne}}=\left(X_{\mathrm{Ca}}\right)^{3}\left(X_{\mathrm{Al}}\right)^{2}
\end{aligned}
$$

In using this model the authors assume ideal mixing and take into account ordering and coupled substitutions to the extent that they are known. Tetrahedral substitution of $\mathrm{Al}$ for $\mathrm{Si}$ is ignored on the basis that it is not independent, but rather is coupled by charge considerations to substitutions of other cations amounting to local charge balance. This model is supported for diopside-tchermakite solid solution by experiments of Wood (1976), who shows that activities of $\mathrm{CaA}_{1} \mathrm{~A}_{1} \mathrm{SiO}_{6}$ in clinopyroxene are approximately equal to the mole fractions of $\mathrm{CaA} 1 \mathrm{~A}_{1} \mathrm{SiO}_{6}$.

Reactions (4) and (5) are plotted (Fig. 3) using the activities calculated in Table 4 for actual mineral compositions. The kyanite-sillimanite boundary
(Newton 1966a; Richardson et al. 1968; Holdaway 1971) and the maximum stability of the $\mathrm{F}_{95}$ analyzed by Jaffe et al. (1978) are shown for comparison. The pressure change of reaction (4) corresponds to a temperature shift of $-14^{\circ} \mathrm{C}$ at point [Fo]. Because merwinite has not been found at Cascade Slide, its activity is set equal to one and a maximum shift for reaction (5) is calculated to be $+0.6 \mathrm{~kb}$ at [Fo]. If merwinite should take up some $\mathrm{Zn}, \mathrm{Mn}$ or $\mathrm{Fe}$ in equilibrium with akermanite, diopside and monticellite, this effect will be diminished. The combined effect of these shifts is to move point [Fo] from $6.4 \mathrm{~kb}, 750^{\circ} \mathrm{C}$ to $7.0 \mathrm{~kb}$, $750^{\circ} \mathrm{C}$. The principal errors in calculation of the shift of this invariant point are in the activity models used. It is believed that the magnitude of such errors is not large in this case where phases are near to endmember composition. Although such error cannot be rigorously evaluated, the authors feel that uncertainties of $\pm 1 \mathrm{~kb}$ and $\pm 30^{\circ} \mathrm{C}$ are conservatively large.

\section{Other Equilibria}

The conditions of metamorphism at Cascade Slide are also restricted by assemblages of grossular-rich garnet + quartz and by forsterite + monticellite. Garnet is restricted by:

$$
\begin{aligned}
& \text { grossular }+ \text { quartz }=\text { wollastonite }+ \text { anorthite } \\
& \mathrm{Ca}_{3} \mathrm{Al}_{2} \mathrm{Si}_{3} \mathrm{O}_{12}+\mathrm{SiO}_{2}=2 \mathrm{CaSiO}_{3}+\mathrm{CaAl}_{2} \mathrm{Si}_{2} \mathrm{O}_{8}
\end{aligned}
$$

Grossular-rich garnet + quartz are found at Cascade Slide, but not coexisting with wollastonite + anorthite. Garnet + quartz will nevertheless provide a minimum pressure at known temperature if $\alpha_{G r}$ is known. A maximum stability for the Cascade Slide garnets $\left(\alpha_{\mathrm{Gr}}=0.6\right)$ is plotted in Fig. 3 assuming that the activities of anorthite and wollastonite equal one. Data on the end-member reaction are from experiments by Newton (1966b) and Boettcher (1970). At $750^{\circ} \mathrm{C}$ the Cascade Slide garnet-quartz assemblage requires $P>5 \mathrm{~kb}$.

The solvus relations between monticellite and forsterite offer a potential geothermometer. This relationship has been experimentally and theoretically investigated in several studies that are summarized by Warner and Luth (1973). In the ideal $\mathrm{CaMgSiO}_{4}-$ $\mathrm{Mg}_{2} \mathrm{SiO}_{4}$ system, Warner and Luth report very limited solid solution of about $1 \mathrm{~mole} \%$ each of forsterite in monticellite and monticellite in forsterite at $800^{\circ} \mathrm{C}$, $10 \mathrm{~kb}$. This solid solution increases to $5 \%$ at $1,200^{\circ} \mathrm{C}$ and is nearly independent of pressure variation from 1 to $10 \mathrm{~kb}$. Monticellite coexists with forsterite at Cascade Slide, but the presence of Fe and Mn precludes direct application of the solvus. The analysis 
of primary contiguous grains from sample LP 77-201 is given in Table 4 where $\mathrm{Fe}$ is the largest additional component with $8.5 \%$ kirschsteinite $\left(\mathrm{CaFeSiO}_{4}\right)$ substitution in monticellite and 3.3\% fayalite substitution in olivine. Similar analyses are reported by Tracy et al. (1978) who also describe occasional fine forsterite lamellae in monticellite. Such lamellae are found in the analyzed monticellite of this study but no attempt was made to reintegrate them as they represent less than $1 \%$ of the host. The effect of $\mathrm{Fe}$ and $\mathrm{Mn}$ on solvus compositions has not been experimentally evaluated, but the partitioning of $\mathrm{Fe}$ into monticellite over forsterite suggests that the effect in the $\mathrm{Ca}_{2}$ $\mathrm{SiO}_{4}-\mathrm{Fe}_{2} \mathrm{SiO}_{4}-\mathrm{Mg}_{2} \mathrm{SiO}_{4}$ ternary could be significant. In the absence of experimental data, all that can be concluded is that these coexisting compositions are consistent with equilibration at relatively low temperature, i.e. $T \leqq 800^{\circ} \mathrm{C}$.

\section{Discussion}

The results of all the systems studied give a selfconsistent, well constrained estimate for the conditions of metamorphism at Cascade Slide. The chemically analyzed assemblage akermanite + monticellite + wollastonite indicates $T=750 \pm 30^{\circ} \mathrm{C}$, in agreement with the regional temperature contours of Bohlen et al. $(1980 \mathrm{~b})$. At $750^{\circ} \mathrm{C}$ the analyzed akermanite indicates $P \leqq 7.0 \pm 1 \mathrm{~kb}$ and, because there is no reason to expect extreme pressure gradients in the granulite facies, the presence of an iron-rich orthopyroxene (Fs ${ }_{95}, 8 \mathrm{~km}$ away) restricts $P \geqq 7.8 \pm 1 \mathrm{~kb}$. These pressure and temperature results are consistent with the less restrictive assemblages of grossular + quartz and monticellite + forsterite and indicate metamorphic conditions in the sillimanite field of $7.4 \pm 1 \mathrm{~kb}$ and $750 \pm 30^{\circ} \mathrm{C}$

These results indicate metamorphism at the peak of the Grenville orogeny and preclude a high-temperature and/or low-pressure contact metamorphic event for the last equilibration of these rocks. Two theories for the timing of anorthosite intrusion are consistent with this conclusion: (1) the Adirondack anorthosite intruded pre-tectonically, and the resulting contact aureole was overprinted by the later granulite facies event, or (2) the anorthosite intruded syn-tectonically with contact temperatures equal to those of the regional metamorphism. The agreement of pressures and temperatures at Cascade Slide with the regional trend argues against a third possibility, post-metamorphic anorthosite intrusion. Pre- or syn-metamorphic intrusion is consistent with the structural interpretation of McLelland (1979) in the Southern Adirondacks.
The close agreement of the pressure and temperature estimates for Cascade Slide provides one of the best known points on a granulite facies geotherm. It is thus tempting to speculate about the heat source of this event which took place several hundred degrees above the average geotherm at 1 b.y. The correlation of high pressures and high temperatures seen in the Central Adirondack Highlands suggests that post-metamorphic domical uplift has been important. Similar, and possibly related uplift is operating in the Adirondacks today (Isachsen and Wold 1977). Such a theory is consistent with either theory 1 or 2 of anorthosite timing. Alternatively, if the anorthosite intruded syntectonically (theory 2), a significant amount of energy would have been provided by the large $10,000 \mathrm{~km}^{3}$ body of anorthositic magma, which coexisting igneous pyroxenes indicate was $1,100^{\circ} \mathrm{C}$ upon intrusion (Bohlen and Essene 1978). These high igneous temperatures would have been dissipated by the cooler country rock to form a regional temperature aureole. This is consistent with geophysical data showing a low gravity and magnetic anomaly for approximately the same region as is outlined by the $700^{\circ} \mathrm{C}$ isotherm (Isachsen et al. 1979). These gravity and magnetic measurements do not vary over areas with and without outcropping anorthosite and could indicate that shallowly buried anorthosite correlates with the $700^{\circ} \mathrm{C}$ isotherm. The final resolution of this question may ultimately have to wait until direct dates are obtained, perhaps from $\mathrm{Nd} / \mathrm{Sm}$ isotopes, which will resolve the question of timing for anorthosite intrusion.

Acknowledgements. This research was supported by National Science Foundation Grants No. EAR 75-22388 and EAR 78-22568, GSA Penrose Research Grant No. 2264-77 and the Turner Fund, University of Michigan. W.C. Bigelow and L.G. Allard of the Engineering College, The University of Michigan, have provided excellent microprobe facilities. We wish to thank Hatten S. Yoder, Jr., for the loan of experimental run products and for a helpful, critical review of this manuscript. We also wish to thank Y.W. Isachsen and J.M. McLelland for informative and profitable excursions in the Adirondacks. The authors have enjoyed stimulating discussions on Adirondacks problems with A.F. Buddington. Finally we thank H.W. Jaffe for providing us with a copy of T.A. Baillieul's MS thesis on Cascade Slide.

\section{References}

Baillieul TA (1976) The Cascade Slide: a mineralogical investigation of a calc-silicate body on Cascade Mountain, Town of Keene, Essex County, New York. MS thesis, University of Massachusetts, $127 \mathrm{p}$

Birch F (1966) Compressibility: elastic constants. In: Clark SP Jr (ed) Handbook of Physical Constants. Geol Soc Am Mem 97:97-174

Boettcher $\mathrm{AL}$ (1970) The system $\mathrm{CaO}-\mathrm{Al}_{2} \mathrm{O}_{3}-\mathrm{SiO}_{2}-\mathrm{H}_{2} \mathrm{O}$ at high pressures and temperatures. J Petrol 11:337-79

Bohlen SR, Boettcher AL, Dollase WA, Essene EJ (1980a) The 
effect of manganese on olivine-quartz-orthopyroxene stability. Earth Planet Sci Lett (in press)

Bohlen SR, Essene EJ (1977) Feldspar and oxide thermometry of granulites in the Adirondack Highlands. Contrib Mineral Petrol 62:153-169

Bohlen SR, Essene EJ (1978) Igneous pyroxenes from metamorphosed anorthosite massifs. Contrib Mineral Petrol 65:433-442

Bohlen SR, Essene EJ, Hoffman K (1980b) Feldspar and oxide thermometry in the Adirondacks: an update. Geol Soc Am Bull 91:110-113

Bowen NL (1940) Progressive metamorphism of siliceous limestone and dolomite. J Geol 68:225-274

Buddington AF (1939) Adirondack igneous rocks and their metamorphism. Geol Soc Am, Mem 7:353 p

Burnham C, Wayne (1959) Contact metamorphism of magnesian limestones at Crestmore, California. Geol Soc Am Bull 70:879 920

de Waard D (1969a) Annotated bibliography of anorthosite petrogenesis. In: YW Isachsen (ed) Origin of Anorthosite and related rocks: NY State Museum and Science Service Mem 18. Albany, NY pp 1-12

de Waard D (1969b) Facies series and $P-T$ conditions of metamorphism in the Adirondack Mountains: Koninkl Nederl Akademie Van Wetenschappen, series B, 72 (2): 134-131

Emmons Ebenezer Report on the Second District of the State of NY, 228-229 (1842)

Greenwood HJ (1967) Wollastonite: stability in $\mathrm{H}_{2} \mathrm{O}-\mathrm{CO}_{2}$ mix tures and occurrence in a contact-metamorphic aureole near Salmo, British Columbia, Canada. Am Mineral 52:1669-1680

Haas JL Jr, Robinson GR Jr, Hemingway BS (1979) Thermodynamic data for $\mathrm{CaO}-\mathrm{Al}_{2} \mathrm{O}_{3}-\mathrm{SiO}-\mathrm{H}_{2} \mathrm{O}$ system. EOS 60:968

Harker RI, Tuttle OF (1956) The lower limit of stability of akermanite $\left(\mathrm{Ca}_{2} \mathrm{MgSi}_{2} \mathrm{O}_{7}\right)$. Am J Sci $254: 468-478$

Helgeson HC, Delany JM, Nesbitt HW, Bird DK (1978) Summary and critique of the thermodynamic properties of rock-forming minerals. Am J Sci 278-A:229 p

Holdaway MJ (1971) Stability of andalusite and the aluminum silicate phase diagram. Am J Sci $271: 97-131$

Isachsen YW, Brown CE, Zietz I (1979) Preliminary interpretation of an aeromagnetic map of most of the Adirondack Mountains and Upper St. Lawrence Valley, New York. Geol Soc Am Abstr w Prog 11:17

Isachsen YW, Fisher DW (1970) Geologic map of New York: Adirondack Sheet, New York State Museum and Sci Service Map and Chart Series, no 15

Isachsen YW, Wold RJ (1977) Geodetic, geological, and geophysical evidence for Holocene vertical movements in the Adirondack region. NY. Geol Soc Am Abstr Progr 9(3):278-279

Jaffe HW, Robinson P, Tracy RJ (1978) Orthoferrosilite and other iron-rich pyroxenes in micro-perthite gneiss of the Mt. Marcy Area, Adirondack Mountains. Am Mineral 63:1116-1136

Joesten R (1974) Metasomatism and magmatic assimilation at a gabbro-limestone contact, Christmas Mountains, Big Bend Region, Texas. Ph D thesis, California Institute of Technology, $397 \mathrm{p}$
Kemp JG (1920) Geology of the Mount Marcy Quadrangle, Essex County, NY. NY State Mus Bull, $86 \mathrm{p}$

Kerrick DM (1974) Review of mixed-volatile $\left(\mathrm{H}_{2} \mathrm{O}-\mathrm{CO}_{2}\right)$ equilibria. Am Mineral 59:729-762

Kerrick DM, Darken LS (1975) Statistical thermodynamic models for ideal oxide and silicate solid solutions, with application to plagioclase. Geochim Cosmochim Acta 39:1431-1442

Kushiro I., Yoder HS Jr (1964) Breakdown of monticellite and akermanite at high pressures. Carnegie Inst Washington Yearb $63: 81-83$

McLelland J (1979) Structural synthesis of the central and southern Adirondacks, New York. Geol Soc Am, Abstr Progr 11:44

Moore PB, Araki T (1972) Atomic arrangement of merwinite, $\mathrm{Ca}_{3} \mathrm{Mg}\left(\mathrm{SiO}_{4}\right)_{2}$, an unusual dense-packed structure of geophysical interest. Am Mineral 57;1355-1374

Newton RC (1966a) Kyanite-sillimanite equilibrium at $750^{\circ} \mathrm{C}$. Science $151: 1222-1225$

Newton RC (1966b) Some calc-silicate equilibrium relations. Am J Sci 264:204-222

Richardson SW, Bell PW, Gilbert MC (1968) Kyanite-sillimanite equilibrium between $700^{\circ}$ and $1,500^{\circ} \mathrm{C}$. Am J Sci $266: 513-541$

Valley JW, Essene EJ (1977) Regional metamorphic wollastonite in the Adirondacks. Geol Soc Am, Abstr Progr 9:306-307

Valley JW, Essene EJ (1979) Vesuvianite, akermanite, monticellite and wollastonite equilibria and high $\mathrm{X}_{\mathrm{H}_{2} \mathrm{O}} / \mathrm{CO}_{2}$ at Cascade Slide, Mt Marcy Quad, Adirondack Mts. Trans Am Geophys Union $60: 423$

Valley JW, Essene EJ (1980) Calc-silicate reactions in Adirondack marble: the role of fluids + solid solution, Parts I and II. Geol Soc Am Bull 91:114-117, 720-815

Wall VJ, Essene EJ (1972) Subsolidus equilibria in $\mathrm{CaO}-\mathrm{Al}_{2} \mathrm{O}_{3}-$ $\mathrm{SiO}_{2}-\mathrm{H}_{2} \mathrm{O}$. Geol Soc Am, Abstr Progr 4:700

Walter LS (1963) Experimental studies on Bowen's decarbonation series. Am J Sci 261:488-500, 773-779

Warner RD, Luth WC (1973) Two-phase data for the join monticellite $\left.(\mathrm{CaMgSiO})_{4}\right)$-forsterite $\left(\mathrm{Mg}_{2} \mathrm{SiO}_{4}\right)$ : experimental results and numerical analysis. Am Mineral 58:998-1008

Westrum EF, Essene EJ, Perkins D III (1979) Thermophysical properties of the garnet, grossular: $\mathrm{Ca}_{3} \mathrm{Al}_{2} \mathrm{Si}_{3} \mathrm{O}_{12}$. J Chem Thermodyn $11: 57-66$

Willemse J, Bensch JJ (1964) Inclusions of carbonate rocks in gabbro and norite of the eastern part of the Bushveld Complex. Trans Geol Soc South Africa 67:1-87

Winkler HGF (1976) Petrogenesis of metamorphic rocks. SpringerVerlag, New York, $320 \mathrm{p}$

Wood Bernard J (1976) Mixing properties of tschermakitic pyroxenes. Am Mineral 61:599-602

Yoder HS Jr (1968) Akermanite and related melilite-bearing assemblages. Carnegie Inst Washington Yearb 66:471-477

Yoder HS Jr (1975) Relationship of melilite bearing rocks to kimberlite: a preliminary report on the system akermanite- $\mathrm{CO}_{2}$. Phys Chem Earth 9:883-894

Accepted June 25, 1980 